\title{
Gluteal nerves in Crab-eating fox
}

\author{
SENOS, R. ${ }^{1,2 *}$ and BENEDICTO, H. G. ${ }^{3}$ \\ ${ }^{1}$ Departamento de Morfologia, Universidade Federal Fluminense - UFF, Rua Prof Hernani de Melo, 101, \\ CEP 24210-130, Niterói, RJ, Brazil \\ ${ }^{2}$ Programa de Anatomia dos Animais Domésticos e Silvestres, Faculdade de Medicina Veterinária e Zootecnia, \\ Universidade de São Paulo - USP, Avenida Professor Orlando Marques de Paiva, 87, \\ CEP 05508-270, São Paulo, SP, Brazil \\ ${ }^{3}$ Departamento de Morfologia, Instituto Biomédico, Universidade Federal Fluminense - UFF, \\ Rua Prof Hernani de Melo, 101, CEP 24210-130, Niterói, RJ, Brazil \\ *E-mail: rafaelsenos@yahoo.com.br
}

\begin{abstract}
Introduction: The Crab-eating fox is a medium-sized South American canid. Although there are several studies regarding this species, especially in epidemiology and parasitology studies, only few data regarding the morphology has been reported. The aim of our study was to describe the gluteal nerves of the Crab-eating fox and compare them with the domestic dogs for homology concerns and surgical application. Materials and Methods: We used four pelvic limbs of Crab-eating foxes fixed with $10 \%$ formalin and injected with red neoprene latex. Muscles, arteries and nerves were anatomically dissected. Results: The Cranial gluteal nerve supplied the Middle gluteal, Deep gluteal and Tensor Fasciae Latae muscles, while the Caudal gluteal nerve supplied the Middle Gluteal, Superficial Gluteal, Pirirformis, Gemilli and Coccygeus muscles. Conclusions: Our results presented a variable relation between muscles and nerve supplies between the Crabeating fox and the domestic dogs. The findings also suggested morphological differentiation in lumbosacral plexus during canids species evolution. Finally, for surgical approaches to hip joint and pelvis, the domestic dog can be used as model for the Crab-eating fox.
\end{abstract}

Keywords: anatomy, Canidae, lumbosacral plexus, neuroanatomy, veterinary.

\section{Introduction}

The Crab-eating fox is a medium-sized South American species, which belongs to Canidae family. It is widely found in South America, except for Chile, Equator and French Guiana (NOWAK, 1991; TCHAICKA, EIZIRIK, OLIVEIRA et al., 2007). The Crab-eating fox is a nocturnal species, with generalist habits, usually found alone or in pairs when feeding (ROCHA, REIS and SEKIAMA, 2004).

Although many studies - over than 130, more than 50 in last 4 years - have already been published regarding this species, just few of them reported morphological aspects (BARISSON, LOURO, DIAS et al., 2012; SENOS and BENEDICTO, 2014). Classic titles describe the anatomy of lumbosacral plexus of the domestic animals in details (EVANS and CHRISTENSEN, 1979; GETTY, 1986; KÖNIG and LIEBICH, 2011) but not in wild carnivores.

Our study aimed to describe the anatomy of the gluteal nerves of the Crab-eating fox using anatomical dissection methods and compare the results with the domestic dog for homology concerns and surgical application.

\section{Short Communication}

We used four pelvic limbs of two adult males of Cerdocyon thous from the collection of the Department of Morphology of the Universidade Federal Fluminense. The limbs were fixed with $10 \%$ formalin solution by muscular injections. To distinguish small nerves and arteries in pictures, we filled the arterial system with red neoprene latex through abdominal aorta injection.

The dissection of the cutaneous and subcutaneous tissue of the gluteal region and thigh were made showing the pelvic limb muscles. After the muscle exposure, we cut transversally the Superficial gluteal muscle close to the femoral insertion and extended it dorsally. In addition, we also cut the insertion of the Middle gluteal muscle and extended it cranially. Finally, we transversally sectioned the Piriformis muscle in the insertion and extended it dorsally.

The Nomina Anatomia Veterinaria (WORLD..., 2005) was applied.

We found the origin of both Cranial gluteal nerve, Caudal gluteal nerve and ischiatic nerve in the Major ischiatic forame. The Cranial and Caudal gluteal nerves supplied the Tensor Fasciae Latae, Deep Gluteal, Middle Gluteal, Superficial Gluteal, Piriformis, Gemilli and Coccygeus muscles (Figure 1). No anatomical variation was found.

\section{Cranial gluteal nerve}

From the Major ischiatic foramen, the Cranial gluteal nerve ran cranially and distally sending muscular branches. The first branch spread into the Middle gluteal muscle (Figure 2). The second branch ran cranially and distally, passed through the Deep gluteal muscle and reached the Tensor Fasciae Latae muscle (Figure 2). The third last branch of the Cranial gluteal nerve was sent directly to the Deep gluteal muscle (Figure 2). 


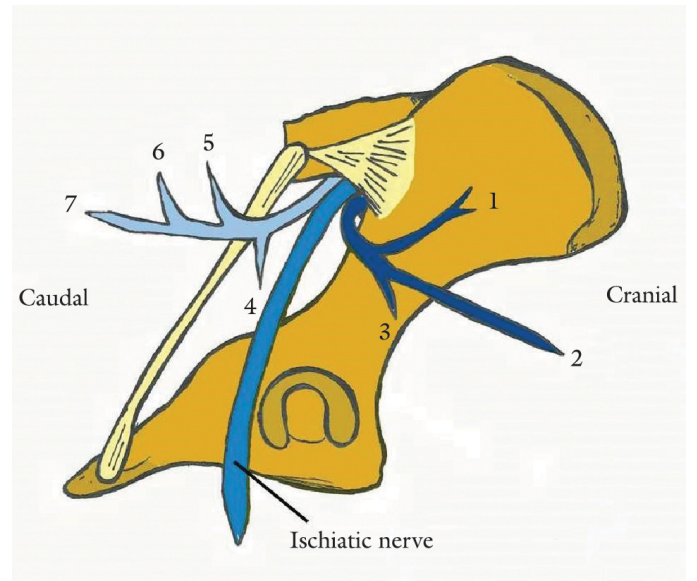

Figure 1. Scheme of the gluteal nerves origin and destination in the Crab-eating fox. Lateral view of the right pelvis. Dark blue $=$ Cranial gluteal nerve; light blue $=$ Caudal gluteal nerve . Muscular branches: 1) Middle gluteal muscle; 2) Tensor fasciae latae muscle; 3) Deep gluteal muscle; 4) Middle gluteal nerve; 5) Piriformis muscle; 6) Superficial gluteal muscle; 7) Gemelli and coccygeus muscles.

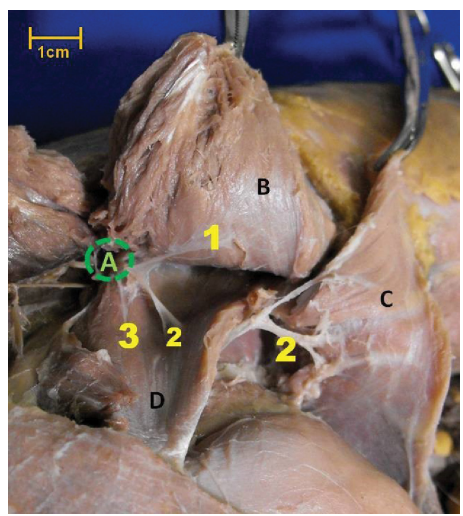

Figure 2. Lateral view of a left gluteal region with detail in the branches of the Cranial gluteal nerve. A) Major ischiatic foramen; B and 1) Middle gluteal muscle and nerve branch; C and 2) Tensor fasciae latae and nerve branch; D and 3) Deep gluteal muscle and branch.
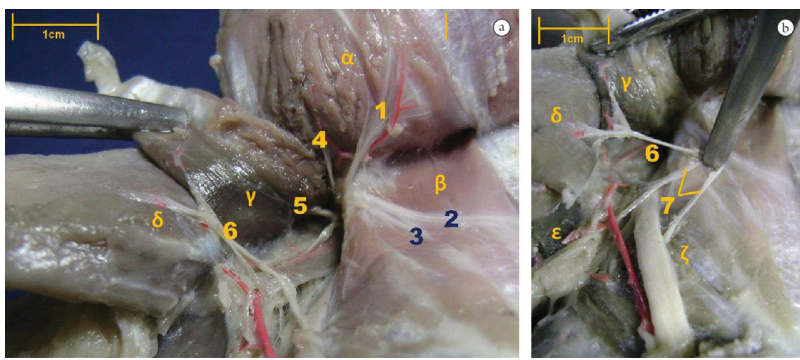

Figure 3. Lateral view of the right gluteal region of the Crabeating fox. a) Branches of the Cranial and Caudal gluteal nerves supplying each muscle. b) Detail on last muscular branches of the Caudal gluteal nerve. 1-3) Branches of the Cranial gluteal nerve. 4-7) Branches of the Caudal gluteal nerve. $\alpha$ ) Middle gluteal muscle; $\beta$ ) Deep gluteal muscle; $\gamma$ ) Piriformis muscle; $\delta)$ Superficial gluteal nerve; $\varepsilon$ ) Coccygeus muscle; $\zeta$ ) Gemilli muscle.

\section{Caudal gluteal nerve}

The Caudal gluteal nerve emerged from the Major ischiatic foramen to caudal direction. The first branch was sent to the Middle Gluteal muscle, caudally to the Cranial gluteal nerve secondary branches. The second branch reached the proximal third of the Piriformis muscle. The third branch was sent as trunk with two small secondary branches to supply both the Superficial gluteal muscle and the Piriformis muscle. The next branch, the fourth, ran directly to the Coccygeus muscle. The last branch penetrated into the Gemilli muscle (Figure 3).

\section{Discussion}

Our results indicate that the Crab-eating fox have similar muscular components of the gluteal region in comparison to dogs (EVANS and CHRISTENSEN, 1979; GETTY 1986; KÖNIG and LIEBICH, 2011). However, there is a variable relation between the nerves of the lumbosacral plexus and their respective muscles. This way, we are not in agreement with the criterion used for muscles homology and homonym defended in previous studies (ROMER and PARSONS, 1985; NITSCHKE, 1972) that take nerves as invariable reference for the muscles.

Another notable finding is the Caudal gluteal nerve supply to Coccygeus and Gemilli muscles in the Crab-eating fox. When comparing species, Coccygeus and Gemilli muscles of the domestic dog are usually supplied respectively by pudendal and ischiatic nerves (EVANS and CHRISTENSEN, 1979; GETTY, 1986; KÖNIG and LIEBICH, 2011). This suggests that during the canids' evolution, some changes occurred around the gluteal innervations. It is known that the Crab-eating fox and the domestic dog shared the same ancestor about 5 million years ago (PERINI, RUSSO and SCHRAGO, 2010) and since then, several morphological changes occurred, not only in the skull (TSENG and WANG, 2010; DAMASCENO, HINGST-ZAHER and ASTÚA, 2013) but also in nerves distribution. This way, for some canid phylogenetic morphological differentiation, the Caudal gluteal nerve can be useful.

In concern to surgical considerations to the gluteal region, the present results suggests that the domestic dog is a good model for the Crab-eating fox on surgical techniques. Although the anatomical differences found in the Caudal gluteal nerves of these species, the course of those differences does not affect surgical approaches to the gluteal region, including the hip joint and pelvis (PIERMATTEI and GREELEY, 1988; JOHNSON and DUNNING, 2005). This agrees to previous statement on applied anatomy for the Crab-eating fox (SENOS and BENEDICTO, 2014). However, for physical examination, it must be remembered that injuries on the Caudal gluteal nerve will also affect the Coccigeus and Gemilli muscle function.

Although the Crab-eating fox wide distribution in nature and recent reports in Parasitology, more morphological data can be useful to understanding zoological aspects and clinical particularities. Our study revealed morphological evolutionary changes in modern canids regarding the lumbosacral plexus. This could be useful for best understanding canids' phylogeny. In addition, we noticed that the domestic dog could be used as a model for surgical purposes in the gluteal region. Studies with more specimens 
are necessary to confirm our results and establish possible anatomical variations for the lumbosacral plexus.

Acknowledgements: We thank Dr Monique Lamhut for revising this manuscript.

\section{References}

BARISSON, JD., LOURO, CH., B, SJT., JOJIMA, FS., FERREIRA, MS. and OLIVEIRA, FS. Anatomo-radiographic description of the axial skeleton of the crab-eating fox (Cerdocyon thous). Pesquisa Veterinária Brasileira, 2012, vol. 32, supplement, p. 1-3. http://dx.doi.org/10.1590/S0100-736X2012001300001

DAMASCENO, EM., HINGST-ZAHER, E. and ASTÚA, D. Bite force and encephalization in the Canidae (Mammalia: Carnivora). Journal Zoology, 2013, vol. 290, n. 4, p. 246-254. http://dx.doi. org/10.1111/jzo.12030

EVANS, HE. and CHRISTENSEN, GC. Miller's anatomy of the dog. Philadelphia: W.B. Saunders Company, 1979. 1181 p.

GETTY, R. Sisson/Grossman anatomia dos animais domésticos. Rio de Janeiro: Guanabara Koogan, 1986. 2000 p.

JOHNSON, AL. and DUNNING, D. Atlas of orthopedic surgical procedures of the dog and cat. Philadelphia: Elsevier, 2005. 247 p.

KÖNIG, HE. and LIEBICH, HG. Anatomia dos animais domésticos. Porto Alegre: Artmed, 2011. 788 p.

NITSCHKE, T. Zusammensetzung der oberflächlichen Gesäßmuskulatur in vergleichedn-anatomischer Betrachtung. Anatomia Histologia Embryologia, 1972, vol. 1, n. 4, p. 363-374. http://dx.doi.org/10.1111/j.1439-0264.1972.tb00973.x

NOWAK, RM. Walker's mammals of the World. Baltimore: The John Hopkins University Press, 1991. 1936 p.
PERINI, FA., RUSSO, CAM. and SCHRAGO, CG. The evolution of South American endemic canids: a history of rapid diversification and morphological parallelism. Journal of Evolutionary Biology, 2010, vol. 23, n. 2, p. 311-322. PMid:20002250. http://dx.doi. org/10.1111/j.1420-9101.2009.01901.x

PIERMATTEI, DL. and GREELEY, RG. Atlas de abordagens cirúrgicas aos ossos do cães e gato. São Paulo: Manole, 1988. 197 p.

ROCHA, VJ., REIS, NR. and SEKIAMA, ML. Dieta e dispersão de sementes por Cerodcyon thous (Linnaeus) (Carnivorae, Canidae), em um fragmento florestal no Paraná, Brasil. Revista Brasileira de Zoologia, 2004, vol. 21, n. 4, p. 871-876. http://dx.doi. org/10.1590/S0101-81752004000400022

ROMER, AS. and PARSONS, TS. Anatomia comparada dos vertebrados. São Paulo: Atheneu, 1985. 560 p.

SENOS, R. and BENEDICTO, HG. Femoral artery in a Crabeating Fox: case report. Journal of Morphological Scienes, 2014, vol. 31, n. 1, p. 54-57. http://dx.doi.org/10.4322/jms.rc053813

TCHAICKA, L., EIZIRIK, E., OLIVEIRA, TG., CÂNDIDO JÚNIOR, JF. and FREITAS, TRO. Phylogeography and population history of the crab-eating fox (Cerdocyon thous). Molecular Ecology, 2007, vol. 16, n. 4, p. 819-838. PMid:17284214. http://dx.doi. org/10.1111/j.1365-294X.2006.03185.x

TSENG, ZJ. and WANG X. Cranial functional morphology of fossil dogs and adaptation for durophagy in Borophagus and Epicyon (Carnivora, Mammalia). Journal of Morphology, 2010, vol. 271, n. 11, p. 1386-1398. PMid:20799339. http://dx.doi.org/10.1002/ jmor.10881

WORLD ASSOCIATION OF VETERINARY ANATOMISTS WAVA. Nomina anatomica veterinaria. Hannover, 2005. 166 p.

Received August 7, 2014 Accepted March 27, 2015 